\title{
Industrialization of construction: Implications on standards, business models and project orientation
}

DOI 10.2478/otmcj-2020-0007

Received December 11, 2019; accepted March 19, 2020

\begin{abstract}
Digitalization has the potential to radically change the way buildings are designed, produced, and operated. In this digital transformation, the establishment of information standards play an important role. However, despite substantial efforts in the development of both technology and standards, these are not yet fully adopted in construction. This study aims to review the adoption of standards and to examine whether suppliers of prefabricated concrete elements have transformed their business models. The purpose is to strengthen the understanding of the interplay between the adoption of standards and business model renewal. Driving forces for the adoption of standards are identified and coupled with suppliers' arguments for business model protection and renewal, explained in terms of a market and a hierarchy approach. The market approach embraces the adoption of open standards for improved competition and information exchange along with the further adoption of industrialized construction. This study identifies that common standards for precast elements are lacking, which leads to waste in terms of structural re-design and liability uncertainties. On the other hand, a market situation with open standards is challenging for suppliers to utilize and benefit from their existing operational platforms. Suppliers of precast elements strive for a hierarchy approach, that is, the
\end{abstract}

*Corresponding author: Niclas Andersson, Faculty of Technology and Society, Malmö University, Nordenskiöldsgatan 1, S-211 19 Malmö, Sweden, E-mail: niclas.andersson@mau.se Jerker Lessing, Department of Civil \& Environmental Engineering, Stanford University, Stanford, CA 94305, USA

(C) 2019 The Authors. Published by Organization Management \& Technology in Construction (OTMC).

This paper is an extended version of Andersson and Lessing (2019a), presented at the Creative Construction Conference 2019, 29 June -

2 July 2019, in Budapest. adoption of the whole value chain, to protect their market position and continue offering structural frameworks and services. This concurs with arguments for industrialized construction, which emphasize the benefits of continuous improvements. This study contributes to the understanding of drivers and impediments for the up-take of standards versus business model renewal in construction.

Keywords: industrialized construction, information standards, business model, precast element, product service system

\section{Introduction}

Digitalization is the single most significant change factor of the whole value chain of construction, with thorough implications on new technology as well as organization and processes (Eadie et al. 2015; Leviäkangas et al. 2017; Rizal 2013; Salman et al. 2012). A strong driver for digitalization in construction is the request for continuous and integrated information exchange between all actors of the construction process (Andersson et al. 2018; Thompson et al. 2017), which will ease communication and collaboration and will facilitate productivity improvements (Edirisinghe and London 2015). The potential of integrated and digital communication and information exchange in construction depends significantly on the establishment of common information standards (Koch 2017), file formats, and business models (Ekholm et al. 2013). Standards constitute a classification of information and rules for the building processes. Andersson et al. (2018) identify three main categories of standards:

- concepts and classifications

- data storage and transfer formats

- information deliveries

There are numerous examples of national and international classification systems developed to support the increasing digitalization in construction. CoClass is one 
example of a new Swedish classification system designed to improve information management in the construction and asset management sector (Smart Built Environment 2017). The CoClass builds largely on the international ISO (ISO 12006-2 and ISO 81346-12) and IEC22 (IEC 81346-2) standard systems and relates to IFC, the global standard for data exchange in the building industries (BuildingSMART, 2020a). Similar classification systems are, for example, the Danish Cuneco Classification System (Cuneco 2013), the OmniClass (OmniClass 2017), created and used by the North American architectural, engineering and construction industry (AEC) and the Uniclass, that supports the construction sectors of the UK.

The civil infrastructure sector demonstrates an example of the need for open standards due to digitalization in the development project called "The Virtual Construction for Roads.” The National Road Authorities of the Netherlands and Sweden initiated this project in 2012 to improve the data exchange in the civil infrastructure sector by developing open standards for exchange and sharing of road information with commercial actors in the sector (Andersson et al. 2018). The background for this initiative was that the private civil infrastructure sector showed limited interest in investing in the standardization of data exchange formats, and therefore, software suppliers did not want to develop software for infrastructure clients as the market potential of their products was considered too uncertain (Koehorst 2017). In the real estate sector, five Swedish public construction client organizations have taken a similar initiative to develop open standards to facilitate the systematic use of BIM in building projects and real estate management (Andersson et al. 2018).

National authorities of Land Survey in Europe take important initiatives for integration between BIM and geographical information systems (GIS), for example, by supporting the EU Directive INSPIRE that will enable the sharing of environmental spatial information among public sector organizations, facilitate public access to spatial information across Europe and assist in policymaking (European Commission 2019). Another example within land surveying is the standard data model and exchange format of CityGML that enables common 3D urban objects of cities and landscapes, such as buildings, roads, rivers, bridges, and vegetation, to be shared and exchanged between applications. CityGML builds upon the Geography Markup Language 3 (GML3) and the international standard for spatial data exchange issued by the Open Geospatial Consortium (OGC) and the ISO TC211 (El-Mekawy et al. 2011). CityGML is also used as an interconnector with IFC to bridge GIS and BIM (de Laat and van Berlo 2010) and enable unified applications in the areas of urban planning, property formation, building permissions as well as building construction analysis and coordination of construction supply chains (Deng et al. 2019; Chognard et al. 2018).

The establishment of Construction Operations Building Information Exchange (COBie) provides an example of a standard data spreadsheet format that facilitates information deliveries from BIM systems to Computer-Aided Facility Management systems for facility's operation and maintenance (FM) (Lee et al. 2013). As such, COBie supports the handover of data from the design and construction phases to the facilities management by incrementally extracting and systematically store relevant FM-information as it emerges from design and construction documentation. The COBie specification rests upon open formats, such as Extensible Markup Language, SpreadsheetML or the IFC STEP format, designed for the exchange of data between systems (Schwabe et al. 2018).

BuildingSMART $(2020 b, c)$ has developed bsDD, the buildingSMART data dictionary, which constitutes an open and international standard library of construction concepts and their attributes. The bsDD allows architects, consultants, owners, and operators on one side and, product manufacturers and suppliers on the other side, to share and exchange product information at a global level (Beetz 2014).

Thus, there are several examples of local, national, and international standard classification systems that share the same fundamental idea of facilitating integrated information flow between systems and actors of the construction process. Such an integrated information infrastructure reaches beyond the AEC industry and includes urban planning, civil infrastructure, real estate management, building material manufacturing, industrialized construction, and other aspects of the construction sector.

\subsection{Problem statement}

Digitalization in construction is transforming the way buildings are conceived, designed, constructed, and operated and bring promises of productivity improvements, ease of communication and collaboration (Leviäkangas et al. 2017; Salman et al. 2012). The development and implementation of common information standards represent an apparent contribution in this process of digitalization (Koch 2017). However, despite rigorous efforts on the development of information standards and considerable advancements in technology, standards have not yet been fully adopted, and benefits from digitalization have not been fully capitalized upon by industry stakeholders 
(Edirisinghe and London 2015). The research reports on several impediments for the implementation of digital solutions and the adoption of standards in construction.

Ghaffarianhoseini et al. (2017) explain the limited uptake of BIM in construction with references to business risks and challenges related to the implementation of new technology and work processes. Rizal (2013) points at commercial and legal barriers as a leading reason for the limited implementation of BIM. The creation of COBie deliverables, mentioned above, is somehow problematic due to incomplete understanding of end-users and insufficient software implementation, which diminish the acceptance among practitioners (Schwabe et al. 2018). Users and implementers of the Data Dictionary, bsDD, hesitate to rely on a single provider for the access of content due to issues of an extensive number of concepts, the dependency of a centralized system, and the constant evolution of vocabulary (Beetz 2014). Koch (2017) refers to a lack of legal demands for using information standards as an impediment to the adoption of information standards. National policy initiatives range from exclusive mandatory requirements to more market-driven laissez-faire approaches, resulting in different implementation levels of digitalization in construction internationally (Edirisinghe and London 2015). Other important barriers for adoption of standards and digitalization in construction relates to the renewed requirements for legal governance, contractual systems, forms of procurement, and business models (Alreshidi et al. 2016; Dixit et al. 2019; Arshad et al. 2019; BIM Alliance 2016).

Accordingly, construction digitalization and adoption to new standard systems provide thorough change processes for all stakeholders that need to reconsider their business models, protect and/or reconfigure their commercial offers, and balance the risk distribution with their customers and suppliers to develop their competitive advantage and maintain their revenue (Smart Built Environment 2019).

\subsection{Purpose, objectives, and delimitations}

This study aims to identify and review the adoption of standards and business model renewal for industrialized suppliers of precast concrete elements to bring light on the driving mechanisms for the adoption of standards versus business model renewal.

The empirical data collected from industrial suppliers of precast concrete elements, in this study, referred to as precast suppliers, are delimited to Swedish companies and their operation on the Swedish construction market. The same geographical limitation goes for the contractors, property developers, and trade organizations covered in the study. All these companies and organizations represent well-established, strong, and large players in their respective lines of business. The literature review relies on international references, and some comparisons are made between the Swedish and the Nordic market of precast concrete.

\section{Method}

This qualitative study operates in the business interface between industrialized and project-based construction. To understand, describe, and critically review the business relations and adoption of standards among precast suppliers, contractors, property developers, and trade organizations, semi-structured interviews were carried out with key representatives in this field. All interviews were recorded, transcribed, and were sent back to the respective respondents for proofreading and eventual corrections in the documentation. Additional data collected through the literature studies and product documentation, that is, the examination of model-generated drawings and technical documentation of precast products, supplemented the interviews. Altogether, the interview series included 11 interviews with key representatives from 10 different companies and organizations representing the industrialized as well as the project-based side of construction. See companies, lines of businesses, and roles of the interviewees in the list below.

- Abetong AB (Abetong 2019), precast supplier, head of the division

- Akademiska Hus (Akademiska Hus 2018), state-owned property company, expert

- Assoc. of Swedish Building Materials Merchants (Byggmaterialhandlarna 2019), trade organization, project manager

- BoKlok (BoKlok 2019), housing developer/prefab, head of research and development

- IKANO Bostad (IKANO Bostad 2019), contractor/property developer, head of the production

- NCC (NCC 2019), contractor/property developer, head of research and development

- StruSoft AB (StruSoft AB 2019), software provider/ precast industry, and business unit director

- Tyréns (Tyréns AB 2019), technical consultancy/ precast design, head of the department

- Veidekke Bostad (Veidekke 2019), contractor/property developer, and project developer

One of the interviewed precast suppliers wanted to stay anonymous. 


\section{Industrialized construction}

Fundamentally different production systems aggravate the establishment of common information standards and coherent information exchange in industrialized and project-based construction (Cox and Ireland 2002). Complex and unique products, temporary organizations, and onsite production methods (Gann and Salter 2000; Gosling and Naim 2009) characterize project-based construction, which offers limited incentives and possibilities for systematical repetition and improved production methods (Dubois and Gadde 2010). Industrialized construction represents a systematic, controlled, and standardized production process of well-defined elements and building systems, which facilitates the collection of experiences from the design, production, and assembly of the building system as a basis for continuous improvements (Lessing 2015). The understanding of industrialized construction has evolved over the years, from the mere off-site prefabrication of building elements to the design and manufacturing of more complex building systems, for example, complete structural frameworks composed by a specific set of slabs, walls, pillars, and beams (Lidelöw et al. 2015). The precast suppliers reviewed in this study operate as manufacturers of standard precast elements as well as suppliers of complete structural frameworks for buildings.

\section{The business model framework of precast suppliers}

The review of business models and information standards among precast suppliers in this study has its starting point in the business model framework for industrial house-building companies presented by Brege et al. (2014). This business model consists of the operational platform, the market position and, the offering (Figure 1).

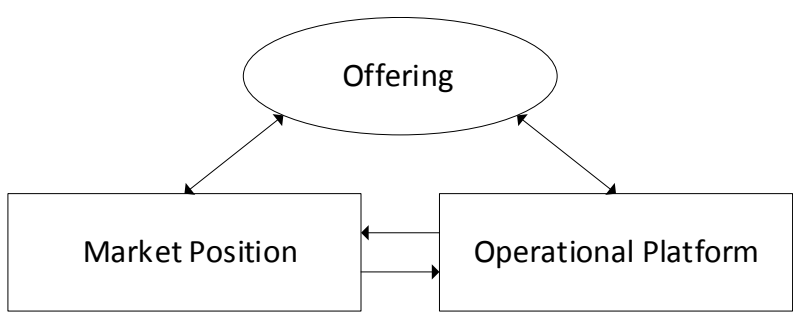

Fig. 1: The business model framework used as the basis of analysis (Brege et al. 2014).

\subsection{The operational platform}

The operational platform describes the precast suppliers' internal structure of resources, competencies and production facilities, but it also includes activities and operations such as management, planning, design, supply chain, and information and communication systems (Liker 2004; Ohno 1988; Bellgran and Säfsten 2009). Thus, the operational platform provides the foundation from which the companies' offers derive.

All the precast suppliers in this study have made considerable investments in sophisticated industrial production facilities, capable of producing all kinds of precast elements. The operational platforms also include sophisticated services in terms of customization of elements, structural design of building systems, planning and logistical services, as well as clash detection and coordination with MEP-suppliers. Overall, the operational platforms of the precast suppliers must be considered well developed and highly competitive.

\subsection{The offering}

The offering represents the products and services provided by precast suppliers. There are two distinct types of offers identified among the precast suppliers. The first is the traditional offer of precast elements such as concrete pillars, columns, stairs, walls, and slabs. Even though this type of offer is highly focused on standardized products, they also involve some customization for the unique needs of each building project.

The other type of offering includes the whole concept of structural design, manufacturing, logistical services, and assembly of complete precast concrete structural frameworks. This offering is an example of complex structural concrete frameworks composed of several standardized and well-documented building elements of precast concrete slabs, walls, pillars, and beams. Offerings that systematically combine both tangible products and intangible services are commonly referred to as product-service systems (PSS) (Manzini and Vezzoli 2003; Mont 2002; Tukker and Tischner 2006). With PSS-offerings, the business' focus shifts from the design and manufacturing of physical products to a combined offering of products and services (Manzini and Vezzoli 2003). Strong drivers for the precast suppliers' development of their PSSofferings are the extended possibilities for customization (Mont 2002), the establishment of long-term business relationships (Manzini and Vezzoli 2003), and extended business opportunities (Andersson and Lessing 2019b). 
The precast suppliers find it difficult to compete solely by producing a standard set of precast elements. Besides, PSS-systems enable systematic, controlled, and standardized production processes that make it possible for the precast supplier to monitor and gather experiences from the design, manufacturing, logistics, and assembly of the precast elements as a basis for continuous improvements (Lessing 2015). This study will refer to the precast suppliers' offerings of complete precast structural frameworks as PSS-offerings.

\section{The market position}

The market position of the business model framework describes how precast suppliers relate to their customers on the market. The precast suppliers in this study operate in two principal lines of business. The offering of standard precast elements with minor customization represents the traditional line of business, in which general contractors constitute the typical client. In this line of business, the precast suppliers act in the role of a manufacturer of building elements with limited involvement in the onsite building production.

The other line of business represents the PSSofferings of complete precast structural frameworks and additional services. In this line of business, the precast supplier operates as a contractor with full responsibility for the design and construction of the structural framework. Accordingly, the precast supplier acts on behalf of the building client, cooperates with the design team, and is directly involved in the onsite production side by side with the general contractor.

\section{Standards versus business models}

\subsection{Standards for precast concrete elements}

The precast suppliers in this study produce more or less the same set of products, that is, concrete walls, slabs, pillars, beams, and stairs. However, despite the almost identical range of products, there is no common standard for the classification of various precast elements and their properties. Instead, all precast suppliers have developed their company-specific classification systems with the unique nomenclature and geometrical definitions of their concrete elements (Table 1).
Tab. 1: Examples of precast suppliers' naming of the different types of concrete elements.

\begin{tabular}{llll}
\hline Product & Supplier A & Supplier B & Supplier C \\
\hline Wall (solid) & V & RV & V \\
Wall (sandwich) & RW & RW & W \\
Pillar (circular) & P or OP & OP & P \\
Pillar (rectangular) & P or RP & RP & P \\
\hline
\end{tabular}

The lack of common standards impedes the precast suppliers' communication and information exchange with their clients or members of the design team. Further, it prevents the integration between the structural design of precast and in-situ frameworks and renders numerous situations of rework, that is, waste, when a structural design solution for in-situ production needs translation into a corresponding solution for precast manufacturing (Andersson and Lessing 2017).

The other Nordic countries of Finland and Norway show a different situation about national standards for the design of structural frameworks. The Finish publication series of "Common BIM requirements 2012" includes hitherto 13 sections, with common requirements for models and model information contents. Section 5 in this series covers structural BIM-modeling and the required information content of the BIM models produced by the structural designer (COBIM 2012). These common BIM requirements are to be mandatorily applied in all design contracts in Finland. Besides, the Finish BES system represents a specific standard system for precast elements that build upon standard modular dimensions for slabs, interior and external walls, bathrooms, staircases, and other precast elements of standard dimensions (Warszawski 2005). The precast elements can be configured within the constraints of the modular dimensions and the defined element interconnections. Corresponding standard systems for industrialized construction is prevalent in Norway (Edirisinghe and London 2015), where the civil state client of Statsbygg has presented a BIM guideline (Statsbygg 2013).

Despite the obvious advantages of open standards for precast structural frameworks, as in Finland, the Swedish precast suppliers express reluctance, or at least hesitation, about the adoption of open standards. Any structural engineer can execute the structural design for precast elements based on open standards, and the situation is the same for logistical services and assembly of precast elements on site. Consequently, open standards for precast elements will challenge the market for PSS-offerings and reduced the precast suppliers to mere manufacturers of precast elements. 


\subsection{Business models for precast suppliers}

The precast suppliers require early involvement in the project process to fully compete and harvest the full business potential of their PSS-offerings. Too late involvement will lead to unnecessary waste in terms of re-design of the structural framework and will render uncertainties about responsibilities for the structural design. The precast suppliers get involved early in a project, for example, when hired directly by the building client, which can be the case in separated coalitions. In this situation, the precast supplier works closely with the architect and other technical engineers from the initial briefing and design stage of the project.

Early involvement can also be the case when the main contractor in an integrated project coalition procures the precast supplier. However, the contractors' decision about whether to choose a precast or a traditional in-situ structural framework is sometimes a concern of the construction managers on-site rather than the technical engineers in the design phase. The contractors' most pronounced benefits of precast structural frameworks are time-saving, improved working conditions, and better logistics, which all directly relate to improved conditions on the construction site. Consequently, decisions about applying precast suppliers are sometimes taken late even in integrated project coalitions.

The problem of late involvement is the same in the project with separated coalitions when the contractor procures the precast supplier after the architectural and structural design has been already completed by the initial design team. The original design documentation is typically done with an in-situ structural framework in mind. Consequently, the precast supplier needs to redesign the structural framework to adapt it to a precast structural framework.

The given situation, with two parallel design solutions, raises questions and uncertainties about responsibilities between the original team of the architectural and structural design and the structural designer of the precast structural framework (Andersson and Lessing 2017).

\section{Conclusions}

This study, operating in the business interface between industrialized and project-based construction, identifies driving forces for the adoption of standards from a market perspective that counteracts with the precast suppliers' arguments for market protection. Incentives for the adoption of standards as well as renewed business models provide an example of a power balance between market and hierarchy (Williamson 1973).

The market approach promotes the adoption of open standards for the prefabrication industry, as in Finland. This approach will open up the market and making it possible for different actors using the same set of common standards to perform their respective parts of the value chain of precast elements. For example, one actor can do the structural design while another actor does the manufacturing of precast element and a third actor performs the logistical service as well as the assembly of the precast elements on site. Open standards, thus, promote increased competition, support information exchange, and prevent the identified problems design rework when shifting from in-situ to precast structural frameworks. The market approach, however, implies a product focus where the market position of the precast supplier is reduced to a mere manufacturer of precast concrete. Competition is based on the lowest price for standard elements of low complexity, and business relations are described by delimited and project-based contracts (Figure 2).

With open standards, the precast suppliers cannot utilize and benefit from their existing operational platforms with qualified structural design competences, logistical services, and resources for onsite assembly. The reserved attitude to the adoption of standards among precast suppliers identified in this study concurs with Koch (2017), who found that actors on markets with no legal demands for the use of standards will only consider the adoption of standards if it generates immediate benefits for the business.

In the hierarchy approach, the precast suppliers try to align the whole value chain of precast structural frameworks to provide PSS-offerings and to secure the most

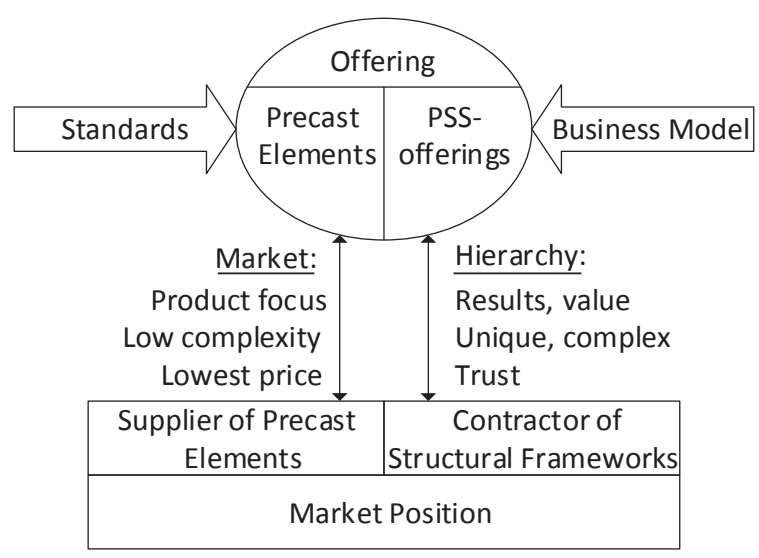

Fig. 2: Implications of standards and business models on offerings and market position. 
efficient use of their operational platforms. As a supplier of PSS-offerings, precast suppliers act as turnkey contractors responsible for the design, manufacturing, deliverance, and assembly of the precast structural framework. This integrated work process provides opportunities for the precast supplier to gather experiences from the design, manufacturing, logistics, and assembly of the precast elements as a basis for continuous improvements. The hierarchy approach enables early involvement, shared risk and rewards, and close collaboration with the design team as well as other contractors. Besides, business relations rely on trust rather than strict contractual agreements, the product is unique and complex and competition is a matter of capabilities and qualities of the expected results. Accordingly, precast suppliers promote their PSS-offers as a way to climb the value chain and get more closely involved in the project-based construction.

The future scenario of the two counteracting forces toward an approach of standards and open market or toward integrated business models and hierarchies is, of course, impossible to forecast. In the long run, however, the adaption and integration of the two approaches are needed to enable the full potential of precast solutions as an integrated part of the construction process.

\section{References}

Abetong, (2019). Abetong AB. [Online] Available at www.abetong. se/en on 14 March, 2019.

Akademiska Hus. (2018). About Akademiska Hus. [Online] Available at www.akademiskahus.se/en/about-us/about-akademiska-hus/ on 14 March, 2019.

Alreshidi, E., Mourshed, M., \& Rezgui, Y. (2016). Requirements for cloud-based BIM governance solutions to facilitate team collaboration in construction projects. Requirements Engineering, 23(1), pp. 1-31.

Andersson, N., \& Lessing, J. (2017). The interface between industrialized and project based construction. Procedia Engineering, 196, pp. 220-227.

Andersson, N., \& Lessing, J., (2019a). Industrialized and Project-Based Construction - Standards Versus Business Models. Budapest, s.n.

Andersson, N., \& Lessing, J. (2019b). Product service systems in construction supply chains. Periodica Polytechnica Architecture, 50(2), pp. 132-138.

Andersson, R., Engström, D., Samuelson, O., \& Stehn, L. (2018). Smart Built Environment Processes and Information Management in Construction and Facility Management. Smart Built Environment, Stockholm.

Arshad, M. F., Thaheem, M. J., Nasir, A. R., \& Malik, M. S. A. (2019). Contractual risks of building information modeling: Toward a standardized legal framework for design-bid-build projects. Journal of Construction Engineering and Management, 145(4), pp. 04019010-13.
Beetz, J. (2014). Towards a Scalable Network of Concept Libraries Using Distributed Graph Databases. CIB W78, Orlando.

Bellgran, M., \& Säfsten, K. (2009). Production Development: Design and Operation of Production Systems. s.l.:Springer Science \& Business Media.

BIM Alliance (2016). BIM - påverkan på affär och avtal. BIM Alliance, Stockholm.

BoKlok. (2019). BoKlok. [Online] Available at www.boklok.se on 3 December, 2019.

Brege, S., Stehn, L., \& Nord, T. (2014). Business models in industrialized building of multistorey houses. Construction Management and Economics, 32(1-2), pp. 208-226.

BuildingSMART. (2020a). Industry Foundation Classes (IFC). [Online] Available at https://technical.buildingsmart.org/standards/ ifc/ on 1 April, 2020.

BuildingSMART. (2020b). About. [Online] Available at www. buildingsmart.org/about/ on 1 April, 2020.

BuildingSMART. (2020c). Data Dictionary (bsDD). [Online] Available at https://technical.buildingsmart.org/standards/bsdd/ on 1 April, 2020.

Byggmaterialhandlarna. (2019). The Association of Swedish Building Materials Merchants. [Online] Available at www. byggmaterialhandlarna.se/the-association-of-swedish-building-materials-merchants/ on 14 March, 2019.

Chognard, S., Dubois, A., Benmansour, Y., \& Torri, D. E. (2018). Digital construction permit: A round trip between GIS and IFC. In: Smith, I., \& Domer, B. (eds.), Advanced Computing Strategies for Engineering. s.l.: Springer, Cham.

COBIM. (2012). Common BIM requirements - Series 5 - Structural design, s.l.: Parties to the COBIM project.

Cox, A., \& Ireland, P. (2002). Managing construction supply chains: The common sense approach. Engineering, Construction and Architectural Management, 9(5-6), pp. 409-418.

Cuneco (2013). Cuneco - centre for productivity in construction. [Online] Available at http://cuneco.dk/english on 8 March, 2019.

de Laat, R., \& van Berlo, L. (2010). Integration of BIM and GIS: The development of the CityGML GeoBIM extension. In: Kolbe, T., König, G., \& Nagel, C. (eds.), Advances in 3D Geo-Information Sciences. S.n., Berlin, pp. 221-225.

Deng, Y., Gan, V. J., Das, M., Cheng, J. C., \& Anumba, C. (2019). Integrating 4D BIM and GIS for construction supply chain management. Journal of Construction Engineering and Management, 145(4), pp. 04019016.

Dixit, M., Venkatraj, V., Ostadalimakhmalbaf, M., Pariafsai, F., \& Lavy, S. (2019). Integration of facility management and building information modeling (BIM): A review of key issues and challenges. Facilities, 37(7/8), pp.455-483.

Dubois, A., \& Gadde, L.-E. (2010). The construction industry as a loosely coupled system: implications for productivity and innovation. Construction Management and Economics, 20(7), pp. 621-631.

Eadie, R., Browne, M., Odeyinka, H., McKeown, C., \& McNiff, S. (2015). A survey of current status of and perceived changes required for BIM adoption in the UK. Built Environment Project and Asset Management, 5(1), pp. 4-21.

Edirisinghe, R., \& London, K. (2015). Comparative Analysis of International and National Level BIM. CIB W78, Eindhoven.

Ekholm, A. o.a. (2013). BIM - Standardiseringsbehov, u.o.: SBUF ID:12690. 
El-Mekawy, M., Östman, A., \& Shahzad, K. (2011). Towards Interoperating CityGML and IFC building models: A unified model based approach. In: Advances in 3D Geo-Information Sciences. Springer, Berlin.

European Commission. (2019). INSPIRE. [Online] Available at https:// inspire.ec.europa.eu/about-inspire/563 on 12 March, 2019.

Gann, D. M., \& Salter, A. J. (2000). Innovation in project-based, service-enhanced firms: The construction of complex products and systems. Research Policy, 29(7-8), pp. 955-972.

Ghaffarianhoseini, A., Tookey, J., Ghaffarianhoseini, A., Naismith, N., Azhar, S., Efimova, O., et al. (2017). Building Information Modelling (BIM) uptake: Clear benefits, understanding its implementation, risks and challenges. Renewable and Sustainable Energy Reviews, 75, pp. 1046-1053.

Gosling, J., \& Naim, M. M. (2009). Engineer-to-order supply chain management: A literature review and research agenda. International Journal of Production Economics, 122(2), pp. 741-754.

IKANO Bostad. (2019). IKANO Bostad. [Online] Available at https:// ikanobostad.se/ on 14 March, 2019.

Koch, C. (2017). Building Information Standards for Innovation in Public Procurement of buildings. Nordic Innovation, Oslo.

Koehorst, B. (2017). Virtual Construction for Roads. [Online] Available at https://cordis.europa.eu/project/rcn/105551/ factsheet/en on 7 March, 2019.

Lee, J., Jeong, W., Faghihi, S. V., \& Kang, J. H. (2013). Automatic Generation of COBIE Data from Revit. s.n., Montréal

Lessing, J. (2015). Industrialised House-Building, Conceptual Orientation and strategic perspectives. Faculty of Engineering, Lund University, Lund.

Leviäkangas, P., Paik, S. M., \& Moon, S. (2017). Keeping up with the pace of digitization: The case of the Australian construction industry. Technology in Society, 50, pp. 33-34.

Lidelöw, H., Enström, D., Jerker, L., \& Stehn, L., (2015). Industriellt husbyggande. Studentlitteratur, Lund.

Liker, J. K. (2004). The Toyota Way: 14 Management Principles from the World's Greatest Manufacturer. McGraw-Hill, New York.

Manzini, E., \& Vezzoli, C. (2003). A strategic design approach to develop sustainable product service systems: Examples taken from the 'environmentally friendly innovation' Italian prize. Journal of Cleaner Production, 11(8), pp. 851-857.

Mont, O. K. (2002). Clarifying the concept of product-service system. Journal of Cleaner Production, 10(3), pp. 237-245.

NCC. (2019). NCC. [Online] Available at www.ncc.group/ on 14 March, 2019.

Ohno, T. (1988). Toyota Production System: Beyond Large-Scale Production. Productivity Press, New York.

OmniClass. (2017). About OmniClass. [Online] Available at www. omniclass.org/about/ on 8 March, 2019.

Rizal, S. (2013). Changing roles of the clients, architects and contractors through BIM. Engineering, Construction and Architectural Management, 18(2), pp. 176-187.

Salman, A., Khalfan, M., \& Tayyab, M. (2012). Building information modelling (BIM): now and beyond. Australasian Journal of Construction Economics and Building, 12(4), pp. 15-28.

Schwabe, K., Dichtl, M., \& Koch, C. (2018). COBie: A specification for the construction operations building information exchange. In: Borrmann, A., König, M., Koch, C., \& Beetz, J. (eds.), Building Information Modeling. s.l.:Springer, Cham.
Smart Built Environment (2017). CoClass - Nya generationen BSAB. Smart Built Environment, Stockholm.

Smart Built Environment. (2019). Smart Built Environment. [Online] Available at www.smartbuilt.se/in-english/ on 6 March, 2019.

Statsbygg. (2013). Statsbygg BIM Manual 1.2.1. Statsbygg, Oslo.

StruSoft AB. (2019). StruSoft. [Online] Available at https://strusoft. com/on 14 March 2019.

Thompson, N., Squires, W., Fearnhead, N., \& Claase, R. (2017). Digitalisation in Construction - Industrial Strategy Review, Supporting the Government's Industrial Strategy. University College London, London.

Tukker, A., \& Tischner, U. (2006). Product-services as a research field: past, present and future. Reflections from a decade of research. Journal of Cleaner Production, 14(17), pp. 1552-1556.

Tyréns AB. (2019). Tyréns. [Online] Available at www.tyrens.se/en/ on 14 March 2019.

Veidekke. (2019). Veidekke Bostad. [Online] Available at https:// www.veidekkebostad.se/ on 14 March 2019.

Warszawski, A. (2005). Industrialized and Automated Building Systems - A Managerial Approach. s.l.:Taylor \& Francis e-Library.

Williamson, O. E. (1973). Markets and hierarchies: some elementary considerations. The American Economic Review, 63(2), pp. 316-325.

\section{Author biography}

Dr. Andersson has been an associate professor at Malmö University, Sweden, since 2014 and was previously employed at the Technical University of Denmark and Lund University (Sweden). His research activities in recent years have primarily concerned BIM-based management of construction as well as industrialized construction, with a focus on standards adoption and business model renewal for industrialized suppliers in construction. His research, for example, identifies and describes counteracting forces between arguments for the adoption of standards and arguments for business renewal and contributes to the understanding of drivers and impediments for the adoption of standards versus business renewal in construction.

Dr. Lessing has been conducted research at Lund University since 2004 and Stanford University since 2013. Since 2015, he is also the director of research and development at BoKlok one of Sweden's leading industrialized construction companies. Dr. Lessing is frequently engaged as a lecturer in both academia and industry and has co-authored a book about industrialized construction, and he publishes his research in international Journals. At Stanford University, Dr. Lessing has established and taught the course CEE324 Industrialized Construction since 2013, organized study trips for students and faculty, to Sweden, as well as organized the Stanford University Industrialized Construction Forum, which is an industry-academia conference held annually. In his research, Dr. Lessing has developed a framework describing contemporary industrialized construction covering technical, organizational, and strategic aspects. His work has served as a foundation for academic research, as well as a guide for the industry's development, in Sweden and internationally. 